\title{
Phencyclidine-Induced Cognitive Deficits in Mice are Improved by Subsequent Subchronic Administration of Fluvoxamine: Role of Sigma-I Receptors
}

\author{
Kenji Hashimoto*,', Yuko Fujita' and Masaomi lyo² \\ 'Division of Clinical Neuroscience, Chiba University Center for Forensic Mental Health, Chiba, Japan; ${ }^{2}$ Department of Psychiatry, Chiba University \\ Graduate School of Medicine, Chiba, Japan
}

\begin{abstract}
This study was undertaken to examine the effects of the selective serotonin reuptake inhibitors fluvoxamine and paroxetine on cognitive deficits in mice after repeated administration of the $\mathrm{N}$-methyl-D-aspartate receptor antagonist phencyclidine (PCP). In the novel object recognition test, repeated administration of PCP $(10 \mathrm{mg} / \mathrm{kg} /$ day, 10 days $)$ significantly decreased the exploratory preference in the retention test session, but not in the training test session. PCP-induced cognitive deficits were significantly improved by subsequent subchronic (2-week) administration of fluvoxamine $(20 \mathrm{mg} / \mathrm{kg} / \mathrm{day})$, but not paroxetine $(10 \mathrm{mg} / \mathrm{kg} /$ day). Furthermore, the effect of fluvoxamine on PCP-induced cognitive deficits was antagonized by co-administration of the selective sigma-I receptor antagonist NE- 100 ( $\mathrm{lmg} / \mathrm{kg} /$ day). Moreover, PCP-induced cognitive deficits were also significantly improved by subsequent subchronic (2-week) administration of the selective sigma-I receptor agonist SA4503 (I mg/kg/day) or neurosteroid dehydroepiandrosterone 3-sulfate (DHEA-S; $25 \mathrm{mg} / \mathrm{kg} / \mathrm{day}$ ). The effects of SA4503 or DHEA-S were also antagonized by co-administration of NE-100 (I mg/kg/day), suggesting the role of sigma-I receptors in the active mechanisms of these drugs. In contrast, acute single administration of these drugs (fluvoxamine, paroxetine, SA4503) alone or combination with NE-I00 did not alter PCP-induced cognitive deficits. The present study suggests that agonistic activity of fluvoxamine at sigma-I receptors plays a role in the active mechanisms of fluvoxamine on PCP-induced cognitive deficits in mice. Therefore, sigma-I receptor agonists such as fluvoxamine would be potential therapeutic drugs for the treatment of the cognitive deficits of schizophrenia.
\end{abstract}

Neuropsychopharmacology (2007) 32, 5I4-521. doi: I0.1038/sj.npp. I 301047; published online 22 February 2006

Keywords: schizophrenia; sigma-I receptor; NMDA receptor; phencyclidine; cognition

\section{INTRODUCTION}

Cognitive deficits in patients with schizophrenia are core features of the illness, and predict vocational and social disabilities for patients (Freedman, 2003; Coyle and Tsai, 2004; Green et al, 2004; Kurtz, 2005). Multiple lines of evidence suggest that a dysfunction in glutamatergic neurotransmission via the $N$-methyl-D-aspartate (NMDA) receptors might be involved in the pathophysiology of schizophrenia (Javitt and Zukin, 1991; Olney and Farber, 1995; Coyle, 1996; Krystal et al, 1999; Moghaddam, 2003; Hashimoto et al, 2003, 2004, 2005b; Javitt, 2004). NMDA receptor antagonists such as phencyclidine (PCP) and ketamine are known to induce schizophrenia-like symp-

*Correspondence: Dr K Hashimoto, Division of Clinical Neuroscience, Chiba University Center for Forensic Mental Health, I-8-I Inohana, Chiba 260-8670, Japan, Tel: +8I 423226 2147, Fax: +8I 423226 2150, E-mail: hashimoto@faculty.chiba-u.jp

Received 7 June 2005; revised 13 December 2005; accepted 19 December 2005

Online publication: 23 January 2006 at http://www.acnp.org/citations/ Npp 12306050374/default.pdf toms, including cognitive deficits and negative symptoms in healthy subjects (Javitt and Zukin, 1991; Krystal et al, 1999); consequently, NMDA receptor antagonists, including PCP and (+)-MK-801 (dizocilpine), have been used widely in animal models of schizophrenia (Hashimoto et al, 1997; Javitt et al, 2004; Jentsch and Roth, 1999; Mandillo et al, 2003; Morimoto et al, 2002; Okamura et al, 2004; SamsDodd, 1998).

We recently found that PCP-induced cognitive deficits in the novel object recognition test could be significantly improved by subsequent subchronic (2-week) administration of clozapine, but not haloperidol. Our observations suggested that reversal of PCP-induced cognitive deficits as measured by the novel object recognition test may be a potential animal model of atypical antipsychotic activity in relation to the amelioration of cognitive deficits in schizophrenia (Hashimoto et al, 2005a).

One approach used to improve cognitive deficits in schizophrenic patients is adjunctive medication to antipsychotic treatment. Some selective serotonin reuptake inhibitors (SSRIs) such as fluvoxamine have shown promising results in patients (Silver, 2001, 2003, 2004; 
Silver et al, 2000), although the precise mechanisms underlying the efficacy of SSRIs on these symptoms are currently unclear. We previously reported that SSRIs possess high to moderate affinity for sigma-1 receptors (Narita et al, 1996). Among the SSRIs, fluvoxamine was the most potent $\left(K_{\mathrm{i}}=36 \mathrm{nM}\right)$ for sigma-1 receptors, and paroxetine was weak $\left(K_{\mathrm{i}}=1893 \mathrm{nM}\right)$ for sigma-1 receptors, suggesting that these receptors may in some way play a role in the mechanisms of action of fluvoxamine (Narita et al, 1996; Hashimoto and Ishiwata, 2006). Multiple lines of evidence suggest that sigma-1 receptors play a role in the pathophysiology of neuropsychiatric diseases such as schizophrenia, anxiety disorders, and depression, as well as in the evolution of cognitive deficits associated with these conditions (Debonnel and de Montigny, 1996; Maurice et al, 2001; Su and Hayashi, 2003; Hayashi and Su, 2004; Takebayashi et al, 2004; Bermack and Debonnel, 2005; Hashimoto and Ishiwata, 2006).

The present study was undertaken to examine the effects of fluvoxamine and paroxetine on PCP-induced cognitive deficits in mice using the novel object recognition test. We also examined the effects of the selective sigma-1 receptor antagonist NE-100 (Okuyama and Nakazato, 1996), the selective sigma-1 receptor agonist SA4503 (Matsuno and Mita, 1998), and the endogenous sigma-1 receptor agonist dehydroepiandrosterone 3-sulfate (DHEA-S) (Urani et al, 2001; Takebayashi et al, 2004) on PCP-induced cognitive deficits in order to study the role of the sigma-1 receptor in the mechanism of action of fluvoxamine.

\section{METHODS}

\section{Animals}

Male ICR mice (6 weeks old) weighing $25-30 \mathrm{~g}$ were purchased from SLC Japan (Hamamatsu, Shizuoka, Japan). Mice in groups of 4 or 5 were housed in clear polycarbonate cages $\left(22.5 \times 33.8 \times 14.0 \mathrm{~cm}^{3}\right)$ under a controlled $12 / 12 \mathrm{~h}$ light-dark cycle (light from 0700 to $1900 \mathrm{~h}$ ), at $23 \pm 1^{\circ} \mathrm{C}$ and $55 \pm 5 \%$ humidity. The mice were given free access to water and food pellets. The experimental procedure was approved by the Animal Care and Use Committee of Chiba University Graduate School of Medicine.

\section{Drugs}

PCP hydrochloride and the selective sigma-1 receptor antagonist NE-100 were synthesized in our laboratory. Fluvoxamine maleate was obtained from Solvay Seiyaku K.K. (Tokyo, Japan); paroxetine hydrochloride and DHEA-S sodium salt from Sigma-Aldrich (St Louis, MO, USA); and the selective sigma-1 receptor agonist SA4503 from M's Science Corporation (Kobe, Japan). Other drugs were purchased from commercial sources.

\section{Drug Administration}

Saline $(10 \mathrm{ml} / \mathrm{kg})$ or PCP $(10 \mathrm{mg} / \mathrm{kg}$ expressed as a hydrochloride salt) were administered subcutaneously (s.c.) for 10 days (once daily on days $1-5$ and $8-12$ ).

In the acute experiment, vehicle $(10 \mathrm{ml} / \mathrm{kg})$ or drugs were administered intraperitoneally (i.p.) into mice 3 days (day

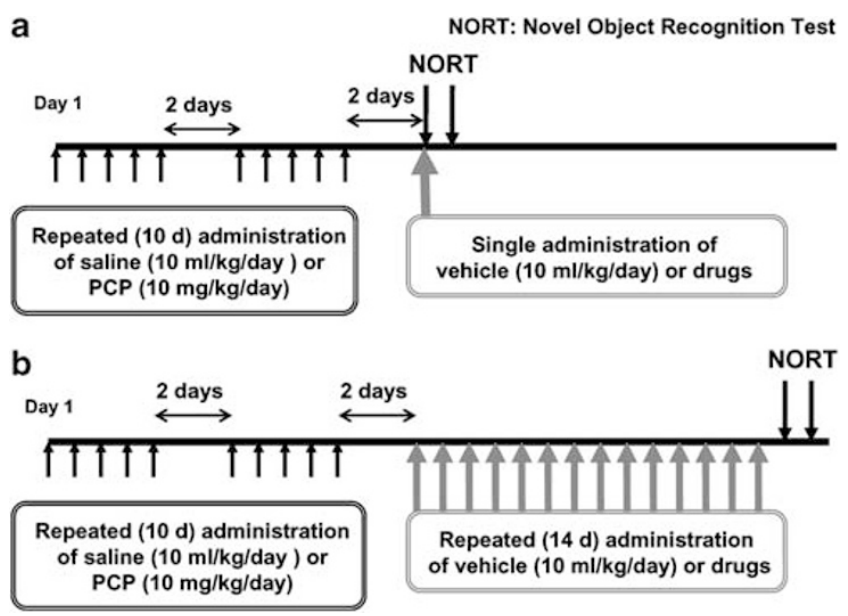

Figure I Treatment schedule. (a) Acute treatment. Saline $(10 \mathrm{ml} / \mathrm{kg})$ or PCP $(10 \mathrm{mg} / \mathrm{kg}$ ) were administered s.c. for 10 days (once daily on days I -5 and 8-12). At 3 days (day 15) after the final administration of saline or PCP, vehicle $(10 \mathrm{ml} / \mathrm{kg})$ or drugs were administered i.p. into mice. The training session for the novel object recognition test was performed $1.5 \mathrm{~h}$ after administration of vehicle or drugs, and the retention test session was performed $24 \mathrm{~h}$ after the training session. (b) Subchronic (2-week) treatment. Saline $(10 \mathrm{ml} / \mathrm{kg})$ or PCP $(10 \mathrm{mg} / \mathrm{kg})$ were administered s.c. for 10 days (once daily on days $1-5$ and $8-12$ ). At 3 days (day 15) after the final administration of saline or PCP, vehicle $(10 \mathrm{ml} / \mathrm{kg})$ or drugs were administered i.p. into mice. This treatment was continued for 2 consecutive weeks (once daily on days 15-28). The training session for the novel object recognition test was performed $24 \mathrm{~h}$ after the final administration of vehicle or drugs, and the retention test session was performed $24 \mathrm{~h}$ after the training session.

15) after the final administration of saline or PCP. The training session of the novel object recognition test was performed $1.5 \mathrm{~h}$ after administration, and the test session was performed $24 \mathrm{~h}$ after the training session as described below (Figure 1a). We also used the novel object recognition test to study the effect of the withdrawal of the drug. In these tests, the training session was performed $24 \mathrm{~h}$ after a single administration of fluvoxamine $(20 \mathrm{mg} / \mathrm{kg})$, and the retention test session was performed $24 \mathrm{~h}$ after the training session.

In the subchronic (2-week) administration experiment, 3 days (day 15) after the final administration of saline or PCP, vehicle or drugs were administered i.p. into mice. This treatment was continued for 2 consecutive weeks (once daily on days 15-28). The training session of the novel object recognition test was performed $24 \mathrm{~h}$ after the final administration, and the retention test session was performed $24 \mathrm{~h}$ after the training session as described below (Figure 1b). Next, we performed the novel object recognition test in order to study the comparative effects of withdrawal of the drug and the duration of treatment. The training session was performed $1.5 \mathrm{~h}$ after the final administration of fluvoxamine $(20 \mathrm{mg} / \mathrm{kg} /$ day for 2 weeks $)$, and the retention test session was performed $24 \mathrm{~h}$ after the training session.

The doses of drugs used in this study were fluvoxamine $(20 \mathrm{mg} / \mathrm{kg})$, paroxetine $(10 \mathrm{mg} / \mathrm{kg}), \mathrm{SA} 4503(1 \mathrm{mg} / \mathrm{kg})$, NE$100(1 \mathrm{mg} / \mathrm{kg})$, and DHEA-S $(25 \mathrm{mg} / \mathrm{kg})$. These doses had been shown to be effective in vivo as sigma-1 receptor agonists or antagonists as reported previously (Sánchez and 
Meier, 1997; Okuyama and Nakazato, 1996; Matsuno et al, 1997; Matsuno and Mita, 1998; Minabe et al, 1999; Zou et al, 2000; Urani et al, 2001).

\section{Spontaneous Locomotor Activity in Mice Treated with Saline or PCP}

At 3 days (day 15) or 17 days (day 29) after the final administration of saline $(10 \mathrm{ml} / \mathrm{kg}$, s.c.) or PCP $(10 \mathrm{mg} / \mathrm{kg}$, s.c.), locomotor activity was measured using an animal movement analysis system (SCANET SV-10, Melquest, Toyama, Japan) as reported previously (Fukami et al, 2004).

\section{Novel Object Recognition Test}

The novel object recognition test was performed as previously reported (Tang et al, 1999, 2001; Hashimoto et al, 2005a; Ozawa et al, 2006). The apparatus for this task consisted of a black open field box $\left(50.8 \times 50.8 \times 25.4 \mathrm{~cm}^{3}\right)$. Before the test, mice were habituated in the box for 3 days. During a training session, two objects (various objects differing in shape and color but similar in size) were placed in the box $35.5 \mathrm{~cm}$ apart (symmetrically), and each animal was allowed to explore in the box for $5 \mathrm{~min}$. The animals were considered to be exploring the object when the head of the animal was facing the object within $2.54 \mathrm{~cm}$ of the object or when any part of the body, except for the tail, was touching the object. The time that mice spent exploring each object was recorded. After training, mice were immediately returned to their home cages, and the box and objects were cleaned with $75 \%$ ethanol to avoid any possible instinctive odorant cues. Retention tests were carried out at 1-day intervals following the respective training. During the retention test, each mouse was placed back into the same box in which one of the objects used during training was replaced by a novel one. The mice were then allowed to explore freely for $5 \mathrm{~min}$, and the time spent exploring each object was recorded. Throughout the experiments, the objects were used in a counterbalanced manner in terms of their physical complexity and emotional neutrality. A preference index, that is, the ratio of the amount of time spent exploring any one of the two objects (training session) or the novel one (retention test session) over the total time spent exploring respective to both objects, was used to measure memory performance.

\section{Statistical Analysis}

Data are expressed as means \pm SEM. Statistical analysis was performed using one-way analysis of variance analysis (ANOVA) and the post hoc Bonferroni test. $P$-values less than 0.05 were considered statistically significant.

\section{RESULTS}

First, we measured spontaneous locomotor activity in mice after repeated administration of saline $(10 \mathrm{mg} / \mathrm{kg} /$ day, s.c.) or PCP $(10 \mathrm{mg} / \mathrm{kg} /$ day, s.c.) (days $1-5$ and $8-12)$. At 3 days (day 15) and 17 days (day 29) after the final administration of saline or PCP, there was no difference between the salinetreated group and the PCP-treated groups in terms of spontaneous locomotor activity (Figure 2).
In the novel object recognition test, we recently reported that the repeated administration of PCP $(10 \mathrm{mg} / \mathrm{kg} / \mathrm{day}$ for 10 days) caused significant cognitive deficits 3 days and 6 weeks after the final administration of PCP (Hashimoto et al, 2005a). In the training session of the present study, the exploratory preferences of the two groups were the same. However, in the retention test session, the exploratory preference (approximately 40\%) of the PCP-treated group was significantly lower than that (approximately 50\%) of the saline-treated group 2 weeks after the final administration of PCP (Figure 3). It seems that small deviations may be important to interpretation since the effects of PCPinduced cognitive deficits are small in this paradigm. During the training session, there were no differences between the saline- and PCP-treated groups in the total amount of time spent exploring the two objects.

In the acute experiments, the effects of a single administration of fluvoxamine $(20 \mathrm{mg} / \mathrm{kg})$, paroxetine $(10 \mathrm{mg} / \mathrm{kg})$, SA4503 (1 mg/kg), NE-100 (1 mg/kg), fluvoxamine $(20 \mathrm{mg} / \mathrm{kg})+\mathrm{NE}-100(1 \mathrm{mg} / \mathrm{kg})$ or SA4503 $(1 \mathrm{mg} / \mathrm{kg})+$ NE-100 $(1 \mathrm{mg} / \mathrm{kg})$ were examined. The training session was performed $1.5 \mathrm{~h}$ after a single administration of vehicle or drug. Then, the retention test session was performed $24 \mathrm{~h}$ after the training session. In the training session, the
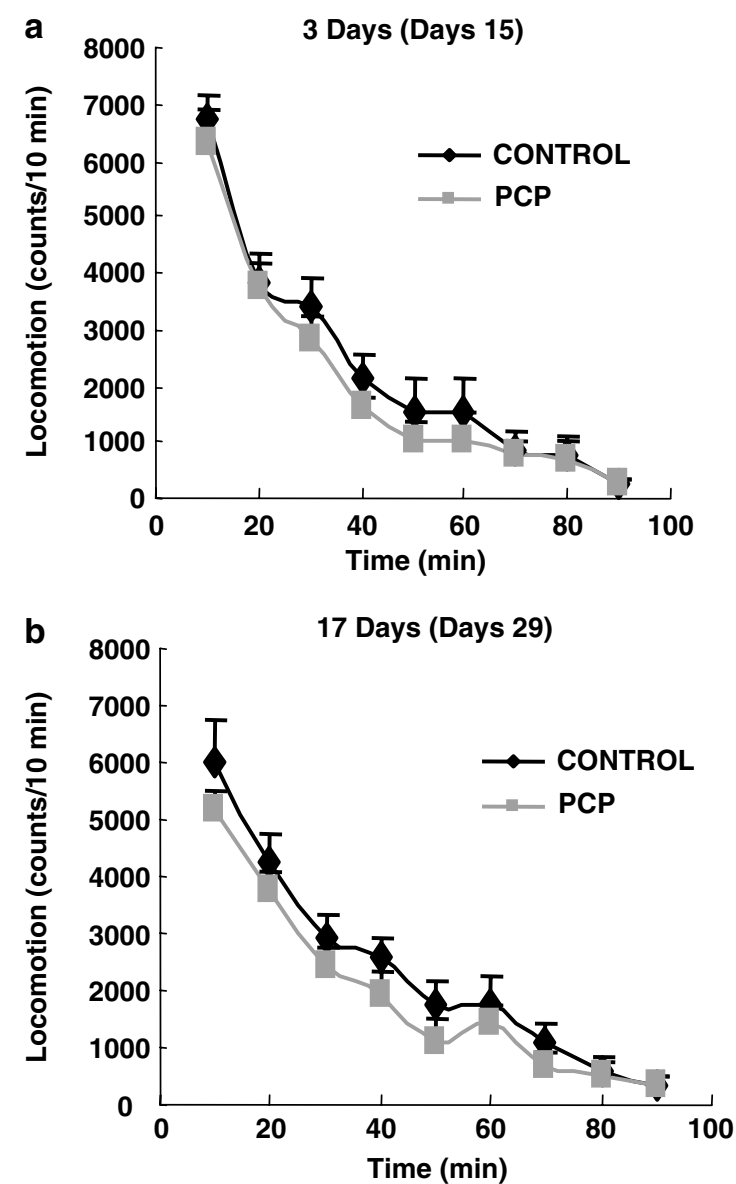

Figure 2 Spontaneous locomotion in mice treated with saline or PCP. Saline $(10 \mathrm{ml} / \mathrm{kg})$ or PCP $(10 \mathrm{mg} / \mathrm{kg})$ were administered s.c. for 10 days (once daily on days $1-5$ and $8-12$ ). Spontaneous locomotor activity in mice was measured 3 days (a: day 15) or 17 days (b: day 29) after the final administration of saline or PCP. 


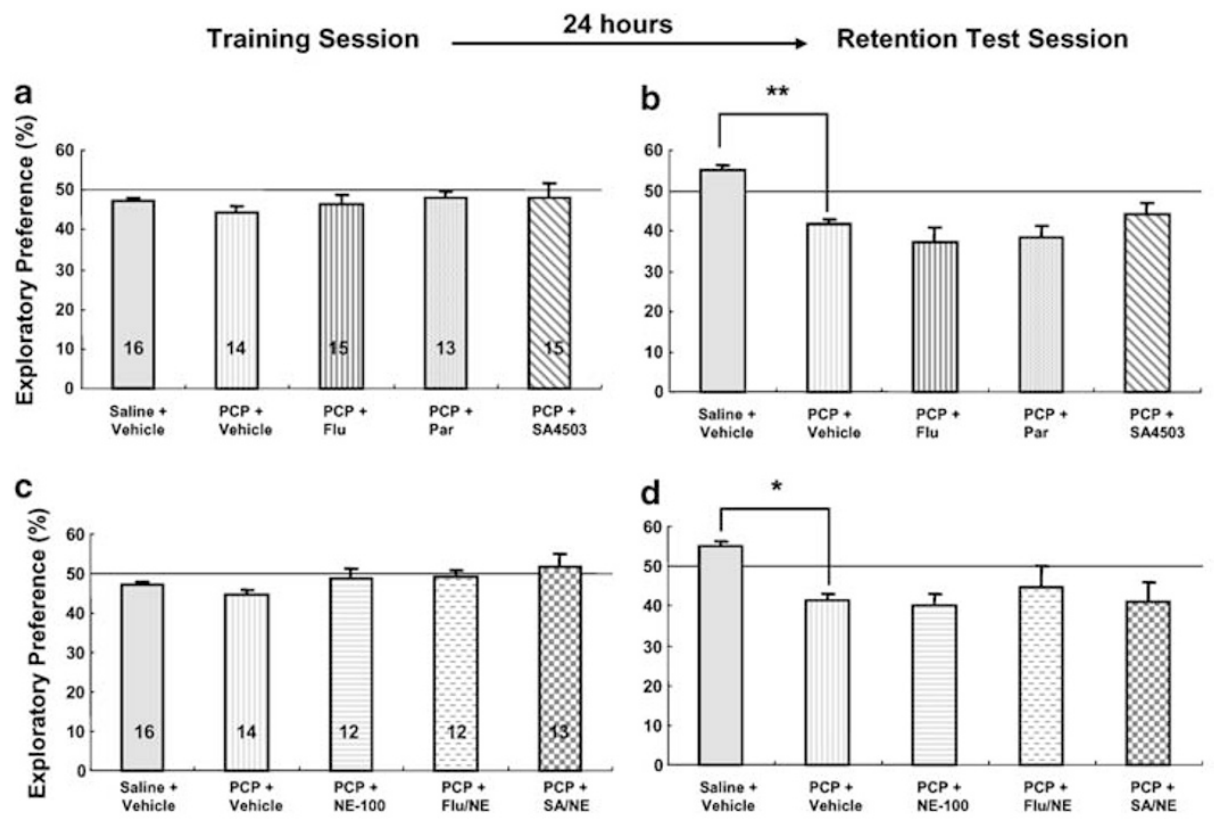

Figure 3 Effects of acute administration of drugs on PCP-induced cognitive deficits in mice. Saline $(10 \mathrm{ml} / \mathrm{kg})$ or PCP $(10 \mathrm{mg} / \mathrm{kg})$ were administered s.c. for 10 days (once daily on days I-5 and 8-12). At 3 days (day 15) after the final administration of saline or PCP, vehicle ( $10 \mathrm{ml} / \mathrm{kg})$, fluvoxamine (20 mg/kg), paroxetine $(10 \mathrm{mg} / \mathrm{kg})$, SA4503 (I mg/kg) or a combination of one of the above with NE- $100(\mathrm{I} \mathrm{mg} / \mathrm{kg})$ were administered i.p. into mice. The training session for the novel object recognition test was performed $1.5 \mathrm{~h}$ after administration of drugs, and the retention test session was performed $24 \mathrm{~h}$ after the training session. Values are means \pm SEM. The numbers on the columns indicate the numbers of animals used. $* p<0.05$, *** $p<0.0$ II as compared with PCP + Vehicle-treated group.

exploratory preference of mice with each of the drug treatments was the same as that of the control group (Figure $3 \mathrm{a}$ and $\mathrm{c}$ ). In the retention test session, none of the drugs altered the reduction of exploratory preference in mice after repeated administration of PCP (Figure $3 \mathrm{~b}$ and $\mathrm{d}$ ). In our study of the effect of the withdrawal of the drug, in which the training session was performed $24 \mathrm{~h}$ after a single administration of fluvoxamine $(20 \mathrm{mg} / \mathrm{kg})$, the single administration of fluvoxamine $(20 \mathrm{mg} / \mathrm{kg}, 24 \mathrm{~h}$ after injection) did not affect PCP-induced cognitive deficits in mice (data not shown). These findings suggest that acute administration of these drugs is ineffective for PCP-induced cognitive deficits in mice.

In contrast, PCP-induced cognitive deficits were significantly improved after subsequent subchronic (2-week) administration of fluvoxamine $(20 \mathrm{mg} / \mathrm{kg} / \mathrm{day})$. In the training session, one-way ANOVA revealed that the exploratory preferences of six groups were not significantly different $(\mathrm{F}[5,112]=1.481, p=0.202)$ (Figure $4 \mathrm{a})$. However, one-way ANOVA did reveal significant differences in the exploratory preferences of the six groups in the retention test sessions $(F[5,112]=5.447, p<0.001)$ (Figure $4 \mathrm{~b})$. The post hoc Bonferroni test indicated that the exploratory preference of the PCP plus vehicle-treated group was significantly $(p<0.001)$ lower than that of the PCP plus fluvoxamine $(20 \mathrm{mg} / \mathrm{kg} /$ day $)$-treated group, but not of groups treated with PCP plus fluvoxamine $(20 \mathrm{mg} / \mathrm{kg} /$ day $) /$ NE-100 ( $1 \mathrm{mg} / \mathrm{kg} /$ day $)$ and PCP plus NE-100 $(1 \mathrm{mg} / \mathrm{kg} /$ day $)$ (Figure $4 \mathrm{~b}$ ). These findings suggest that sigma-1 receptors play a role in the active mechanism of fluvoxamine. Furthermore, in both the training session and the retention test session, the exploratory preferences of the group with subchronic administration of fluvoxamine $(20 \mathrm{mg} / \mathrm{kg} /$ day for 2 weeks) alone were not different from that of the control group (Figure 4). In our study of the comparative effects of the withdrawal of the drug and the duration of treatment, in which the training session was performed $1.5 \mathrm{~h}$ after the final administration of fluvoxamine $(20 \mathrm{mg} / \mathrm{kg} / \mathrm{day}$ for 2 weeks), the fluvoxamine-treated group showed significant improvement of PCP-induced cognitive deficits (data not shown). These data suggest that the effects of fluvoxamine might depend more on the duration of treatment than on the withdrawal of the drug.

The effects of another SSRI paroxetine on PCP-induced cognitive deficits were examined. As shown in Figure 5, PCP-induced cognitive deficits were not affected by the subsequent subchronic (2-week) administration of paroxetine $(10 \mathrm{mg} / \mathrm{kg} /$ day $)$. In the retention test session, one-way ANOVA revealed that the exploratory preferences of three groups were significantly different $(\mathrm{F}[2,54]=5.565$, $p=0.006$ ) (Figure 5b). The post hoc Bonferroni test indicated that the exploratory preference of the PCP plus vehicle-treated group was not statistically significantly different from that of the PCP plus paroxetine-treated group.

Next, we examined the effects of the selective sigma-1 receptor agonist SA4503 $(1 \mathrm{mg} / \mathrm{kg} /$ day for 2 weeks $)$ and the endogenous sigma-1 receptor agonist DHEA-S $(25 \mathrm{mg} / \mathrm{kg} /$ day for 2 weeks). In the training session, one-way ANOVA revealed no difference between the exploratory preferences of the four groups (Figure 6a: $\mathrm{F}[3,61]=0.208, p=0.891$; Figure $7 \mathrm{a}: \mathrm{F}[3,71]=0.603, p=0.615)$. In the retention test 


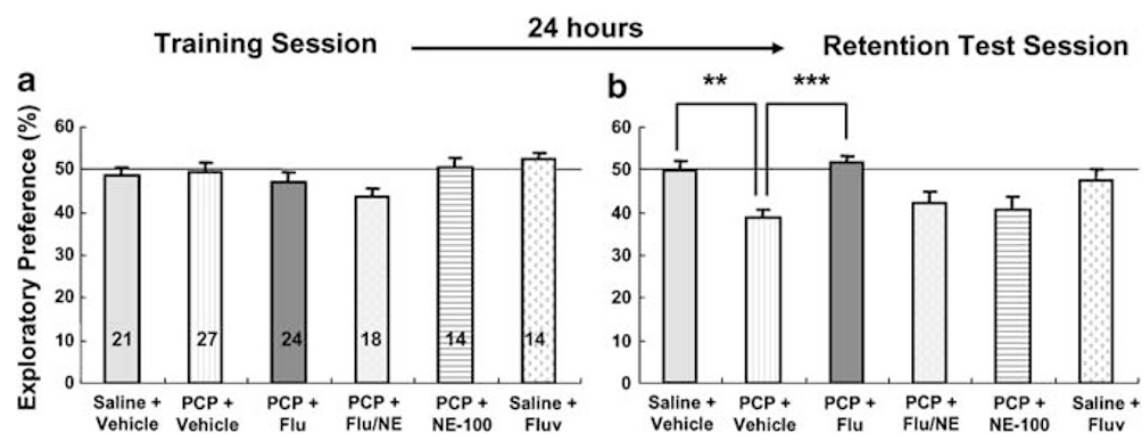

Figure 4 Effects of fluvoxamine on PCP-induced cognitive deficits in mice. Saline $(10 \mathrm{ml} / \mathrm{kg})$ or PCP $(10 \mathrm{mg} / \mathrm{kg})$ were administered s.c. for 10 days (once daily on days $1-5$ and $8-12)$. At 3 days (day 15$)$ after the final administration of saline or PCP, vehicle $(10 \mathrm{ml} / \mathrm{kg})$, fluvoxamine $(20 \mathrm{mg} / \mathrm{kg})$, fluvoxamine $(20 \mathrm{mg} / \mathrm{kg})$ plus NE-100 (I mg/kg), or NE-100 (I mg/kg) were administered i.p. into mice. The treatment was continued for 2 consecutive weeks (once daily on days 15-28). The training session for the novel object recognition test was performed $24 \mathrm{~h}$ (day 29) after the final administration of vehicle or drugs, and the retention test session was performed $24 \mathrm{~h}$ (day 30 ) after the training session. Values are means \pm SEM. The numbers on the columns indicate the numbers of animals used. ${ }^{* *} p<0.01$, **** $<0.001$ as compared with PCP-treated group.

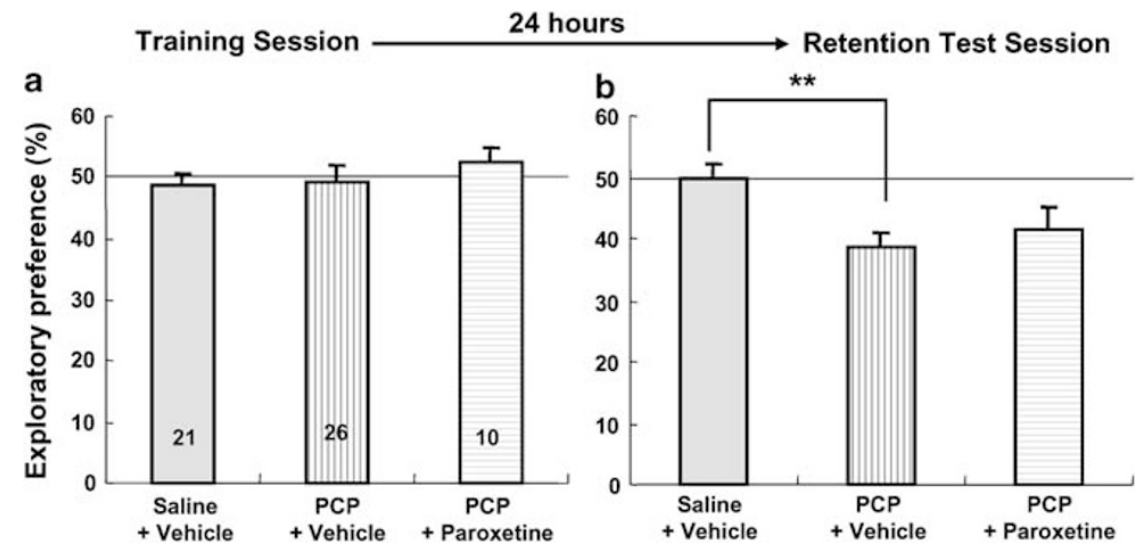

Figure 5 Effects of paroxetine on PCP-induced cognitive deficits in mice. Saline $(10 \mathrm{ml} / \mathrm{kg})$ or PCP $(10 \mathrm{mg} / \mathrm{kg})$ was administered s.c. for 10 days (once daily on days I-5 and 8-12). At 3 days (day I5) after the final administration of saline or PCP, vehicle $(10 \mathrm{ml} / \mathrm{kg})$ or paroxetine $(10 \mathrm{mg} / \mathrm{kg})$ was administered i.p. into mice. The treatment was continued for 2 consecutive weeks (once daily on days 15-28). The training session for the novel object recognition test was performed $24 \mathrm{~h}$ (days 29) after the final administration of vehicle or drugs, and the retention test session was performed $24 \mathrm{~h}$ (days 30 ) after the training session. Values are means \pm SEM. The numbers on the columns indicate the numbers of animals used. $* * p<0.0$ I as compared with PCP $+V$ ehicle-treated group.

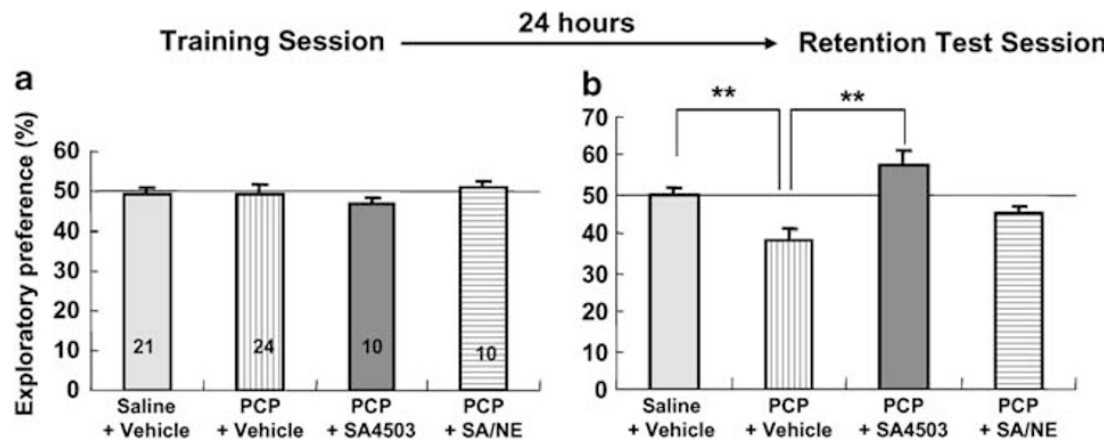

Figure 6 Effects of SA 4503 on PCP-induced cognitive deficits in mice. Saline $(10 \mathrm{ml} / \mathrm{kg})$ or PCP (10 mg/kg) was administered s.c. for 10 days (once daily on days I-5 and 8-12). At 3 days (day I5) after the final administration of saline or PCP, vehicle ( $10 \mathrm{ml} / \mathrm{kg}$ ), SA 4503 (I mg/kg), or SA 4503 plus NE- I00 $(\mathrm{I} \mathrm{mg} / \mathrm{kg}$ ) was administered i.p. into mice. The treatment was continued for 2 consecutive weeks (once daily on days I5-28). The training session for the novel object recognition test was performed $24 \mathrm{~h}$ (day 29) after the final administration of vehicle or drugs, and the retention test session was performed $24 \mathrm{~h}$ (day 30 ) after the training session. Values are means \pm SEM. The numbers on the columns indicate the numbers of animals used. $* * * 0.0 \mathrm{I}$ as compared with PCP + Vehicle-treated group.

session, one-way ANOVA revealed that the exploratory preferences of the three groups were significantly different (Figure $6 \mathrm{~b}: \quad \mathrm{F}[3,61]=7.622, \quad p<0.001 ;$ Figure $7 \mathrm{~b}$ :
$\mathrm{F}[3,71]=6.034, p=0.001)$. The post hoc Bonferroni test indicated that the exploratory preference of the PCP plus vehicle-treated group was significantly lower than that of 

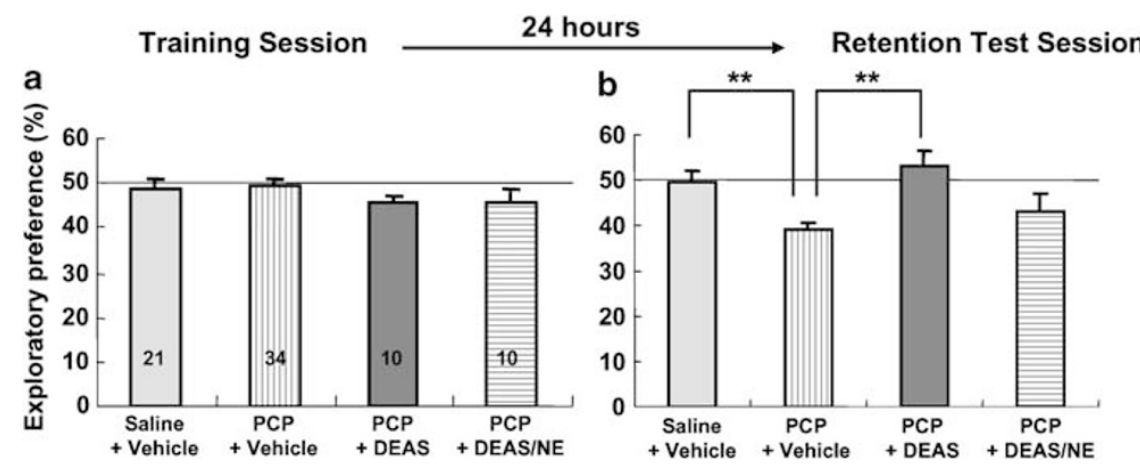

Figure 7 Effects of DHEA-S on PCP-induced cognitive deficits in mice. Saline $(10 \mathrm{ml} / \mathrm{kg})$ or PCP $(10 \mathrm{mg} / \mathrm{kg}$ ) was administered s.c. for 10 days (once daily on days I-5 and 8-12). At 3 days (day I5) after the final administration of saline or PCP, vehicle ( $10 \mathrm{ml} / \mathrm{kg})$, DHEA-S (25 mg/kg), or DHEA-S (25 mg/kg) plus NE-100 (I mg/kg) were administered i.p. into mice. The treatment was continued for 2 consecutive weeks (once daily on days I5-28). The training session for the novel object recognition test was performed $24 \mathrm{~h}$ (day 29) after the final administration of vehicle or drugs, and the retention test session was performed $24 \mathrm{~h}$ (day 30 ) after the training session. Values are means \pm SEM. The numbers on the columns indicate the numbers of animals used. $* * * 0.01$ as compared with PCP + Vehicle-treated group.

the PCP plus SA4503-treated group $(p<0.001)$ or the PCP plus DHEA-S-treated group $(p=0.009)$. However, a single administration of SA4503 $(1 \mathrm{mg} / \mathrm{kg}, 1.5 \mathrm{~h})$ did not alter the exploratory preference of the PCP-treated group in either the training or the retention session (Figure 3).

\section{DISCUSSION}

We reported recently that repeated administration of PCP $(10 \mathrm{mg} / \mathrm{kg} /$ day for 10 days) caused cognitive deficits in mice for more than 6 weeks after the final administration of PCP, and that the PCP-induced cognitive deficits could be improved by subsequent subchronic administration of clozapine, but not haloperidol (Hashimoto et al, 2005a). Therefore, reversal of PCP-induced cognitive deficits as measured by the novel object recognition test may be a potential animal model of atypical antipsychotic activity in relation to the amelioration of cognitive deficits in schizophrenia (Hashimoto et al, 2005a).

The major findings of the present study are that the PCPinduced cognitive deficits could be improved by subsequent subchronic administration of fluvoxamine via sigma-1 receptors. In contrast, we found that paroxetine with no affinity to sigma-1 receptors did not attenuate the PCPinduced cognitive deficits in mice. Furthermore, we found that treatment with the selective sigma-1 receptor agonist SA4503 or the endogenous sigma-1 receptor agonist DHEA$\mathrm{S}$ significantly attenuated PCP-induced cognitive deficits in mice. In addition, the effects of SA4503 and DHEA-S on PCP-induced cognitive deficits were also antagonized by co-administration of the sigma-1 receptor antagonist NE-100, suggesting the role of sigma-1 receptors in the mechanisms of action of SA4503 and DHEA-S. Taken together, it is likely that sigma-1 receptor agonists are potential therapeutic drugs for the treatment of cognitive deficits in schizophrenia.

In the novel object recognition test, no differences in the total amount of time spent exploring the two objects or in exploratory preference were found between saline- and PCP-treated groups during the training session, suggesting that levels of motivation, curiosity, and interest in exploring novel objects were the same in the two groups. Repeated administration of PCP significantly decreased the exploratory preference in the retention test session, but not the training session. In the retention test session, the exploratory preference (approximately 40\%) of the PCP-treated group was significantly lower (by approximately $50 \%$ ) than that of the saline-treated group, suggesting that impairment of novel object exploration may not be due to memory impairment. It seems that small deviations may be important to interpretation since the effects of PCP-induced cognitive deficits are small in the novel object recognition test paradigm. Furthermore, it has been reported that the repeated administration of PCP caused social interaction deficits in animals (Mandillo et al, 2003; Sams-Dodd, 1998). Taken together, it is likely that our model of PCP-induced cognitive deficits using the novel object recognition test may show cognitive deficits in schizophrenia (Hashimoto et al, 2005a).

In this study, we found that PCP-induced cognitive deficits could be improved by subsequent subchronic (2week), but not acute, administration of fluvoxamine. In the novel object recognition test, improvement by fluvoxamine was detected both 1.5 and $24 \mathrm{~h}$ after the final administration of fluvoxamine $(20 \mathrm{mg} / \mathrm{kg} /$ day for 2 weeks), whereas no improvement by fluvoxamine was shown 1.5 and $24 \mathrm{~h}$ after a single administration of fluvoxamine. These data suggest that the effects of fluvoxamine on PCP-induced cognitive deficits in mice depend more on the duration of the treatment than the withdrawal of the drug.

Adjunctive medication to antipsychotic treatment is one approach used to improve several symptoms of schizophrenia (Silver, 2003, 2004). It has been demonstrated that fluvoxamine (relative to the other SSRIs) can improve primary negative symptoms in chronic schizophrenic patients treated with antipsychotic drugs (Silver et al, 2000; Silver, 2001). It is thus possible that sigma-1 receptors may be implicated in the beneficial effects of fluvoxamine, although further studies using specific sigma-1 receptor agonists would be necessary. At present, no studies have been published regarding the effects of post-treatment with fluvoxamine on PCP-induced cognitive deficits in rodents. As described above, we reported that PCP-induced cognitive deficits in mice could be improved by post-treatment with clozapine, but not haloperidol (Hashimoto et al, 
2005a). In the present study, we found that, similar to clozapine, fluvoxamine could improve PCP-induced cognitive deficits in mice. Therefore, it would be of great interest to examine the effects of fluvoxamine on cognitive deficits in schizophrenic patients.

Possible cellular and molecular mechanisms underlying the effects of sigma-1 receptor agonists on PCP-induced cognitive deficits cannot be fully evaluated from the present study. It has been reported that sigma-1 receptors regulate $\mathrm{Ca}^{2+}$ release from intracellular $\mathrm{Ca}^{2+}$ storage sites (Hayashi et al, 2000; Hayashi and Su, 2001, 2004), and that injections of inhibitors of intracellular $\mathrm{Ca}^{2+}$ released into the brain could abolish the effects of sigma-1 receptor agonists in an animal model of depression (Urani et al, 2002). Therefore, it is likely that modulation of $\mathrm{Ca}^{2+}$ signaling by a sigma-1 receptor agonist may play a role in the active mechanism of these drugs in the cognitive deficits paradigm, although further detailed studies are necessary.

In conclusion, the present study suggests that agonistic activity of fluvoxamine at the sigma-1 receptors plays a role in the active mechanisms of fluvoxamine on PCP-induced cognitive deficits, and that sigma-1 receptor agonists could improve PCP-induced cognitive deficits in mice. Therefore, it is likely that drugs that act as sigma-1 receptor agonists, including fluvoxamine, might potentially be used for the treatment of cognitive deficits of schizophrenia.

\section{ACKNOWLEDGEMENTS}

This study was supported in part by grants from the Minister of Education, Culture, Sports, Science, and Technology of Japan $(\mathrm{KH})$ and the Ministry of Health, Labor, and Welfare of Japan (KH).

\section{REFERENCES}

Bermack JE, Debonnel G (2005). The role of sigma receptors in depression. J Pharmacol Sci 97: 317-336.

Coyle JT (1996). The glutamatergic dysfunction hypothesis for schizophrenia. Harv Rev Psychiatry 3: 241-253.

Coyle JT, Tsai G (2004). The NMDA receptor glycine modulatory site: a therapeutic target for improving cognition and reducing negative symptoms in schizophrenia. Psychopharmacology (Berlin) 174: 32-38.

Debonnel G, de Montigny C (1996). Modulation of NMDA and dopaminergic neurotransmissions by sigma ligands: possible implications for the treatment of psychiatric disorders. Life Sci 58: 721-734.

Freedman R (2003). Schizophrenia. N Engl J Med 349: 1738-1749.

Fukami G, Hashimoto K, Koike K, Okamura N, Shimizu E, Iyo M (2004). Effect of antioxidant $N$-acetyl-L-cysteine on behavioral changes and neurotoxicity in rats after administration of methamphetamine. Brain Res 1016: 90-95.

Green MF, Nuechterlein KH, Gold JM, Barch DM, Cohen J, Essock $\mathrm{S}$ et al (2004). Approaching a consensus cognitive battery for clinical trials in schizophrenia: the NIMH-MATRICS conference to select cognitive domains and test criteria. Biol Psychiatry 56: 301-307.

Hashimoto K, Fujita Y, Shimizu E, Iyo M (2005a). Phencyclidineinduced cognitive deficits in mice are improved by subsequent subchronic administration of clozapine, but not haloperidol. Eur J Pharmacol 519: 114-117.

Hashimoto K, Fukushima T, Shimizu E, Komatsu N, Watanabe H, Shinoda N et al (2003). Decreased serum levels of D-serine in patients with schizophrenia: evidence in support of the $\mathrm{N}$-methyl-D-aspartate receptor hypofunction hypothesis of schizophrenia. Arch Gen Psychiatry 60: 572-576.

Hashimoto K, Ishiwata K (2006). Sigma receptor ligands: possible application as therapeutic drugs and as radiopharmaceuticals. Curr Pharm Des (in press).

Hashimoto K, Okamura N, Shimizu E, Iyo M (2004). Glutamate hypothesis of schizophrenia and approach for possible therapeutic drugs. Curr Med Chem CNS Agents 4: 147-154.

Hashimoto K, Shimizu E, Iyo M (2005b). Dysfunction of glianeuron communication in pathophysiology of schizophrenia. Curr Psychiatry Rev 1: 151-163.

Hashimoto K, Tomitaka S, Bi Y, Narita N, Minabe Y, Iyo M (1997). Rolipram, a selective phosphodiesterase type-IV inhibitor, prevents induction of heat shock protein HSP-70 and hsp-70 mRNA in rat retrosplenial cortex by the NMDA receptor antagonist dizocilpine. Eur J Neurosci 9: 1891-1901.

Hayashi T, Maurice T, Su TP (2000). Ca ${ }^{2+}$ signaling via sigma-1 receptors: novel regulatory mechanism affecting intracellular $\mathrm{Ca}^{2+}$ concentration. J Pharmacol Exp Ther 293: 788-798.

Hayashi T, Su TP (2001). Regulating ankyrin dynamics: roles of sigma-1 receptors. Proc Natl Acad Sci USA 98: 491-496.

Hayashi T, Su TP (2004). Sigma-1 receptor ligands: potential in the treatment of neuropsychiatric disorders. CNS Drugs 18: 269-284.

Javitt DC (2004). Glutamate as a therapeutic target in psychiatric disorders. Mol Psychiatry 9: 984-987.

Javitt DC, Balla A, Burch S, Suckow R, Xie S, Sershen H (2004). Reversal of phencyclidine-induced dopaminergic dysregulation by $N$-methyl-D-aspartate receptor/glycine-site agonists. Neuropsychopharmacology 29: 300-307.

Javitt DC, Zukin SR (1991). Recent advances in the phencyclidine model of schizophrenia. Am J Psychiatry 148: 1301-1308.

Jentsch JD, Roth RH (1999). The neuropsychopharmacology of phencyclidine: from NMDA receptor hypofunction to the dopamine hypothesis of schizophrenia. Neuropsychopharmacology 20: 201-225.

Krystal JH, D'Souza DC, Petrakis IL, Belger A, Berman RM, Charney DS et al (1999). NMDA agonists and antagonists as probes of glutamatergic dysfunction and pharmacotherapies in neuropsychiatric disorders. Harv Rev Psychiatry 7: 125-143.

Kurtz MM (2005). Neurocognitive impairment across the lifespan in schizophrenia: an update. Schizophr Res 74: 15-26.

Mandillo S, Rinaldi A, Oliverio A, Mele A (2003). Repeated administration of phencyclidine, amphetamine and MK-801 selectively impairs spatial learning in mice: a possible model of psychotomimetic drug-induced cognitive deficits. Behav Pharmacol 14: 533-544.

Matsuno K, Mita S (1998). SA 4503: a novel sigma-1 receptor agonist. CNS Drug Rev 4: 1-24.

Matsuno K, Senda T, Kobayashi T, Okamoto K, Nakata K, Mita S (1997). SA4503, a novel cognitive enhancer, with sigma-1 receptor agonistic properties. Behav Brain Res 83: 221-224.

Maurice T, Urani A, Phan VL, Romieu P (2001). The interaction between neuroactive steroids and the sigma-1 receptor function: behavioral consequences and therapeutic opportunities. Brain Res Brain Res Rev 37: 116-132.

Minabe Y, Matsuno K, Ashby Jr CR (1999). Acute and chronic administration of the selective sigmal receptor agonist SA4503 significantly alters the activity of midbrain dopamine neurons in rats: an in vivo electrophysiological study. Synapse 33: 129-140.

Moghaddam B (2003). Bringing order to the glutamate chaos in schizophrenia. Neuron 40: 881-884.

Morimoto T, Hashimoto K, Yasumatsu H, Tanaka H, Fujimura M, Kuriyama $M$ et al (2002). Neuropharmacological profile of a novel potential atypical antipsychotic drug Y-931 (8-fluoro-12(4-methylpiperazin-1-yl)-6H-[1]benzothieno[2,3-b][1,5] benzodiazepine maleate). Neuropsychopharmacology 26: 456-467. 
Narita N, Hashimoto K, Tomitaka S, Minabe Y (1996). Interactions of selective serotonin reuptake inhibitors with subtypes of sigma receptors in rat brain. Eur J Pharmacol 307: 117-119.

Okamura N, Hashimoto K, Shimizu E, Kumakiri C, Komatsu N, Iyo $M$ (2004). Adenosine A1 receptor agonists block the neuropathological changes in rat retrosplenial cortex after administration of the NMDA receptor antagonist dizocilpine. Neuropsychopharmacology 29: 544-550.

Okuyama S, Nakazato A (1996). NE-100: a novel sigma receptor antagonist. CNS Drug Rev 2: 226-237.

Olney JW, Farber NB (1995). Glutamate receptor dysfunction and schizophrenia. Arch Gen Psychiatry 52: 998-1007.

Ozawa K, Hashimoto K, Kishimoto T, Shimizu E, Ishikura H, Iyo $M$ (2006). Immune activation during pregnancy in mice leads to dopaminergic hyperfunction and cognitive impairment in the offspring: a neurodevelopmental animal model of schizophrenia. Biol Psychiatry (in press).

Sams-Dodd F (1998). Effects of continuous D-amphetamine and phencyclidine administration on social behaviour, stereotyped behaviour, and locomotor activity in rats. Neuropsychopharmacology 19: 18-25.

Sánchez C, Meier E (1997). Behavioral profiles of SSRIs in animal models of depression, anxiety and aggression. Are they all alike? Psychopharmacology (Berlin) 129: 197-205.

Silver $\mathrm{H}$ (2001). Fluvoxamine as an adjunctive agent in schizophrenia. CNS Drug Rev 7: 283-304.

Silver H (2003). Selective serotonin reuptake inhibitor augmentation in the treatment of negative symptoms of schizophrenia. Int Clin Psychopharmacol 18: 305-313.

Silver H (2004). Selective serotonin re-uptake inhibitor augmentation in the treatment of negative symptoms of schizophrenia. Expert Opin Pharmacother 5: 2053-2058.
Silver H, Barash I, Aharon N, Kaplan A, Poyurovsky M (2000). Fluvoxamine augmentation of antipsychotics improves negative symptoms in psychotic chronic schizophrenic patients: a placebo-controlled study. Int Clin Psychopharmacol 15: 257-261.

Su TP, Hayashi T (2003). Understanding the molecular mechanism of sigma-1 receptors: towards a hypothesis that sigma-1 receptors are intracellular amplifiers for signal transduction. Curr Med Chem 10: 2073-2080.

Takebayashi M, Hayashi T, Su TP (2004). A perspective on the new mechanism of antidepressants: neuritogenesis through sigma-1 receptors. Pharmacopsychiatry 37(Suppl 3): S208-S213.

Tang YP, Shimizu E, Dube GR, Rampon C, Kerchner GA, Zhuo M et al (1999). Genetic enhancement of learning and memory in mice. Nature 401: 63-69.

Tang YP, Wang H, Feng R, Kyin M, Tsien JZ (2001). Differential effects of enrichment on learning and memory function in NR2B transgenic mice. Neuropharmacology 41: 779-790.

Urani A, Roman FJ, Phan VL, Su TP, Maurice T (2001). The antidepressant-like effect induced by sigma-1 receptor agonists and neuroactive steroids in mice submitted to the forced swimming test. J Pharmacol Exp Ther 298: 1269-1279.

Urani A, Romieu P, Portales-Casamar E, Roman FJ, Maurice T (2002). The antidepressant-like effect induced by the sigma-1 receptor agonist igmesine involves modulation of intracellular calcium mobilization. Psychopharmacology (Berlin) 163: 26-35.

Zou LB, Yamada K, Sasa M, Nakata Y, Nabeshima T (2000). Effects of sigma-1 receptor agonist SA4503 and neuroactive steroids on performance in a radial arm maze task in rats. Neuropharmacology 39: 1617-1627. 